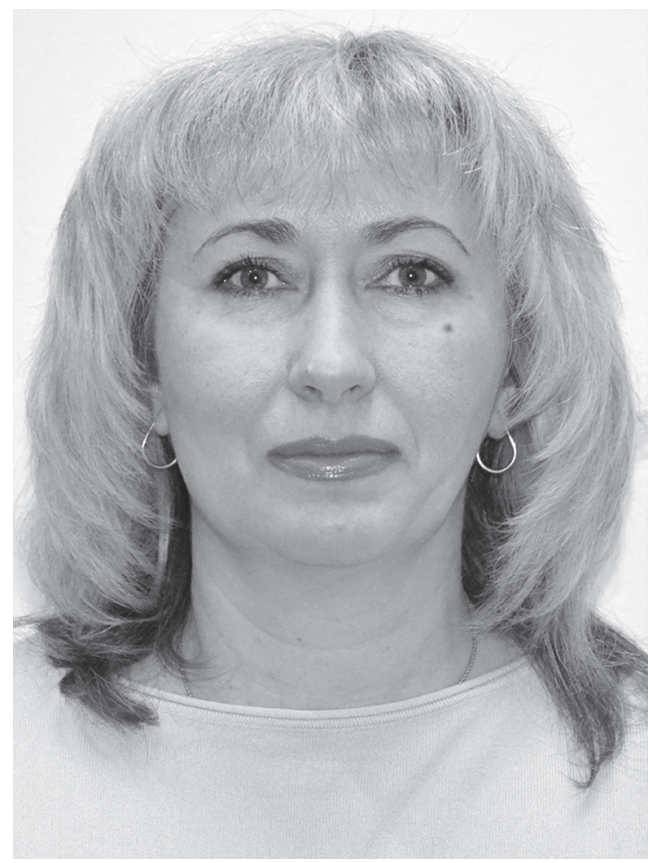

Marchenko Lyudmila Yuryevna, post-graduate student of Personnel Management and Labour Economics Department, KRI NAPA, Deputy Head of Taxation Administration-Head of Department of Expenditures, Administration of State Treasury Service of Ukraine in Kharkiv City, Kharkiv Region, 61051, Kharkiv, Str. Klochkivska, 276-B, f. 107, tel.: (067) 7774705, e-mail: marcheluda@gmail.com ORCID: 0000-0003-3577-0630
УДК: 351.72:336.14

DOI: https://doi.org/10.32689/2617-

2224-2019-18-3-290-300

Марченко Людмила Юрївна,

аспірант кафедри управління персоналом та економіки праці ХарРІ НАДУ, заступник начальника управління - начальник відділу видатків, Управління державної казначейської служби України у м. Харкові Харківської області, 61051, м. Харків, вул. Клочківська, 276-Б, кв. 107, тел.: (067) 7774705, e-mail: marcheluda@gmail.com

ORCID: 0000-0003-3577-0630

Марченко Людмила Юрьевна, аспирант кафедры управления персоналом и экономики труда ХарРИ НАГУ, заместитель начальника управления начальник отдела расходов, Управление государственной казначейской службы Украинь в г. Харькове Харьковской области, 61051, г. Харьков, ул. Клочковская, 276-Б, кв. 107, тел.: (067) 7774705, e-mail: marcheluda@gmail.com

ORCID: 0000-0003-3577-0630

\title{
АРХЕТИПНІ ЗАСАДИ ВПРОВАДЖЕННЯ ТЕХНОЛОГІЙ СТАЛОГО РОЗВИТКУ В СФЕРІ ОБСЛУГОВУВННЯ КЛІЕНТІВ ДЕРЖАВНОЇ КАЗНАЧЕЙСЬКОЇ СЛУЖБИ УКРАЇНИ
}

Анотація. Відзначено, що засновником фундаментальних положень колективного несвідомого, яке складається з архетипів та ідей, є Карл Юнг. Проаналізовано, що на сьогодні досить актуальним є впровадження новітніх інформаційних технологій у сфері обслуговування клієнтів Державною казначейською службою України через призму архетипіки. Зазначено, що трансформація Державної казначейської служби України здійснюється 3 урахуванням засадничих положень архетипіки, у тому числі проводиться 
діяльність щодо збалансування роботи та спрощення взаємодії посадових осіб з клієнтами Казначейства через впровадження новітніх інформаційних систем, що полегшують міжособистісну взаємодію, покращують мікроклімат у колективах органів Казначейства. Обгрунтовано, що рушійною силою в процесі впровадження новітніх технологій у сфері обслуговування клієнтів органами Казначейства є цілеспрямована праця окремої людини, всього колективу. Визначено загальні принципи впровадження технологій сталого розвитку щодо казначейського обслуговування клієнтів. Розглянуто пріоритетні напрями діяльності органів Державної казначейської служби. Схарактеризовано впровадження системи дистанційного обслуговування клієнтів через програмно-технічний комплекс “Клієнт Казначейства - Казначейство”, за допомогою якого забезпечується спрощення та оптимізація взаємодії розпорядників (одержувачів) бюджетних коштів з органами Казначейства, крім того використовується електронний формат обслуговування клієнтів з використанням надійних засобів електронного цифрового підпису та сучасних інтернет-технологій, що зменшує фінансові витрати клієнтів, яких обслуговує Казначейство, а також впливає на завантаженість посадових осіб різноманітною паперовою роботою, що з точки зору колективної свідомості з урахуванням архетипів, які склалися нині в нашій державі, покращує як міжособистісні контакти, так і взаємодію органів державної влади з підприємствами, установами, організаціями загалом. Визначено сучасні проблеми впровадження технологій сталого розвитку у сфері обслуговування клієнтів Державної казначейської служби України та запропоновано заходи, спрямовані на їх вирішення.

Ключові слова: архетип, архетипіка, Державна казначейська служба України, електронний документообіг, електронна звітність, електронне урядування, клієнти, пріоритетні напрями діяльності органів Казначейства, система дистанційного обслуговування, сталий розвиток, технології.

\section{АРХЕТИПИЧЕСКИЕ ОСНОВЫ ВНЕДРЕНИЯ ТЕХНОЛОГИЙ УСТОЙЧИВОГО РАЗВИТИЯ В СФЕРЕ ОБСЛУЖИВАНИЯ КЛИЕНТОВ ГОСУДАРСТВЕННОЙ КАЗНАЧЕЙСКОЙ СЛУЖБЫ УКРАИНЫ}

Аннотация. Отмечено, что основателем фундаментальных положений коллективного бессознательного, которое состоит из архетипов и идей, является Карл Юнг. Проанализировано, что на сегодня достаточно актуальным является внедрение новейших информационных технологий в сфере обслуживания клиентов Государственной казначейской службой Украины через призму архетипики. Отмечено, что трансформация Государственной казначейской службы Украины осуществляется с учетом основных положений архетипики, в том числе проводится деятельность по сбалансированию работы и упрощению взаимодействия должностных лиц с клиентами Казначейства через внедрение новейших информационных систем, облегчающих межличностное взаимодействие, что улучшает микроклимат 
в коллективах органов Казначейства. Обосновано, что движущей силой в процессе внедрения новейших технологий в сфере обслуживания клиентов органами Казначейства является целенаправленная работа отдельного человека, всего коллектива. Определены общие принципы внедрения технологий устойчивого развития относительно казначейского обслуживания клиентов. Рассмотрены приоритетные направления деятельности органов Государственной казначейской службы. Охарактеризовано внедрение системы дистанционного обслуживания клиентов через программно-технический комплекс “Клиент Казначейства - Казначейство”, с помощью которого обеспечивается упрощение и оптимизация взаимодействия распорядителей (получателей) бюджетных средств с органами Казначейства, используется электронный формат обслуживания клиентов с использованием надежных средств электронной цифровой подписи и современных интернет-технологий, что уменьшает финансовые затраты клиентов, которых обслуживает Казначейство, а также влияет на загруженность должностных лиц разнообразной бумажной работой, а также с точки зрения коллективного сознания с учетом архетипов, которые сложились сегодня в нашем государстве, улучшает как межличностные контакты, так и взаимодействие органов государственной власти с предприятиями, учреждениями, организациями в целом. Определены современные проблемы внедрения технологий устойчивого развития в сфере обслуживания клиентов Государственной казначейской службы Украины и предложены меры, направленные на их решение.

Ключевые слова: архетип, архетипика, Государственная казначейская служба Украины, электронный документооборот, электронная отчетность, электронное управление, клиенты, приоритетные направления деятельности органов Казначейства, система дистанционного обслуживания, устойчивое развитие, технологии.

\section{ARCHETYPAL PRINCIPLES OF IMPLEMENTATION OF SUSTAINABLE DEVELOPMENT TECHNOLOGIES IN THE SPHERE OF CUSTOMERS OF STATE TREASURY SERVICE OF UKRAINE}

Abstract. The article notes that Karl Jung is the founder of fundamental positions of the collective unconscious, which consists of archetypes and ideas. It is analyzed that today the introduction of the newest information technologies in the sphere of customer service provided by the State Treasury Service of Ukraine through the prism of archetype. It is outlined that the transformation of the State Treasury Service of Ukraine is carried out taking into account the basic provisions of archetype, including balancing of work and facilitating the interaction of officials with clients of the Treasury through the introduction of the latest information systems that facilitate interpersonal interaction and improve the microclimate in the teams of the Treasury Service. It is substantiated that the deliberate work of the individual person and the whole collective is the motive power of the introduction of the newest technologies in the sphere of customer service 
provided by the Treasury bodies. The general principles of introduction of sustainable development technologies regarding treasury service of clients are determined. Priority directions of the State Treasury Service activity are considered. It is characterized the implementation of the remote customer service through the software and technical complex "Client of the Treasury - Treasury", with the help of which simplification and optimization of spending units (receivers) interaction with Treasury bodies as well as an electronic format of customer service using electronic digital signature and modern Internet technologies are provided. Such electronic services reduce the financial expenses of clients serviced by the Treasury, and also affects the workload of officials by various paper work, which from the point of view of collective consciousness, taking into account the archetypes that have developed in our country today, improves both interpersonal contacts and interaction of state authorities with enterprises, institutions, organizations in general. The modern problems of sustainable development technologies introduction in the sphere clients servicing by the State Treasury Service of Ukraine are determined, and measures aimed at their solution are proposed.

Keywords: archetype, State treasury service of Ukraine, electronic document flow, electronic reporting, e-government, clients, priority areas of Treasury bodies activity, remote service system, sustainable development, technology.

Постановка проблеми. У сучасних умовах глобалізації економіки одним з пріоритетів сталого розвитку в сфері обслуговування клієнтів Державної казначейської служби України є взаємодія та налагодження взаємозв'язку на різних рівнях в управлінні публічними фінансами, що є запорукою підвищення прозорості та ефективності іх розподілу, а також цільового спрямування публічних фінансів на конкретно визначені цілі. Впровадження сучасних інформаційних технологій в органах Державної казначейської служби України (далі - органи Казначейства) дають змогу створити якісно нові форми організації діяльності органів Казначейства та їх структурних підрозділів, оптимізувати взаємодію з органами державної влади та місцевого самоврядування шля- хом надання доступу до державних інформаційних ресурсів, а також покращити якість обслуговування клієнтів Казначейства.

Ключовою проблемою успішного впровадження новітніх інформаційних технологій у сфері казначейського обслуговування клієнтів є обмеженість у часі та належному фінансовому забезпеченні, що ставить під загрозу забезпечення високих темпів економічного зростання та підвищення конкурентоспроможності національної економіки.

Аналіз останніх досліджень і публікацій. Проблематика архетипів сягає своїми витоками аналітичної психології, але завжди залишатиметься міждисциплінарною, позаяк вибудовується на фундаментальних категоріях, поняттях, ідеях як психології, так і психіатрії, політології, 
соціології, державного управління, культурології, філософії. Класичними представниками різних наукових галузей, що в різний час торкалися дослідження архетипів, є Е. Дюркгайм, Гаррі Стек Салліван, 3. Фройд, К. Юнг. Вагомий внесок у розвиток теоретичних положень архетипіки зробили такі сучасні вітчизняні науковці: О. Амосов, Е. Афонін, Н. Гавкалова, В. Омел'яненко, О. Сушій та ін.

У свою чергу, дослідженню питань, пов'язаних з впровадженням новітніх інформаційних технологій, приділяли такі вітчизняні науковці та практики, як С. Булгакова, Т. Кублікова, Е. Курганська, Ю. Пасічник, П. Петрашко, В. Стоян, Н. Сушко, В. Федосов, С. Юрій та ін. Однак з урахуванням постійних трансформаційних процесів в органах Казначейства дослідження проблем щодо впровадження інформаційних технологій, що будуються на принципах архетипіки, вироблених ще в сиву давнину класичними представниками різних наукових течій, у сфеpi казначейського обслуговування клієнтів є актуальним та своєчасним. Необхідно акцентувати увагу на тому, що практично немає наукових праць, присвячених впровадженню новітніх технологій в органах Казначейства.

Мета статті. Аналіз впровадження новітніх інформаційних технологій у сфері обслуговування клієнтів органами Казначейства через призму архетипіки.

Виклад основного матеріалу дослідження. Засновником фундаментальних положень колективного несвідомого, яке складається з архетипів та ідей, є Карл Юнг.
Карл Юнг вважав, що архетип (в аналітичній психології) - це універсальні первинні вроджені психічні структури, які складають зміст колективного несвідомого, що розпізнаються в нашому досвіді і являються, зазвичай, в образах та мотивах сновидінь.

За теорією К. Юнга основними архетипами колективного несвідомого є: самість, аніма та анімус, тінь, маска, мудрець, Бог. Архетип є сенсоформою, загальним значенням, притаманним всім індивідам, що зберігається на рівні колективного несвідомого і виявляється у вигляді символів. Символ є безпосередньою реалізацією архетипу, але ніколи не вичерпує всього багатства його значень. На думку К. Юнга, архетипи мають значення лише реалізовуючись у вигляді символів. Лише цілеспрямована праця та переживання дає людині змогу зрозуміти власні архетипи. К. Юнг вважав, що людина розвивається протягом всього життя. Цей шлях самопізнання, самовдосконалення та самоствердження він назвав - індивідуація. Однією 3 головних життєвих цілей людини є пошук та знаходження самої себе. У цьому контексті ключовим виступає архетип самості [1].

Отже, ми отримали уявлення про науку архетипіку, за допомогою якої можливо скласти розуміння в галузі сучасних науково-практичних досліджень, у тому числі у державному управлінні.

Рушійною силою в процесі впровадження новітніх технологій у сфері обслуговування клієнтів органами Казначейства є цілеспрямована праця окремої людини, всього колективу. 
Використання сучасних методів обробки інформації, безперервної модернізації та удосконалення інформаційних технологій, які використовують органи Казначейства, дає змогу підвищити дієвість й ефективність функціонування системи казначейського обслуговування клієнтів та виконання бюджетів.

Загальними принципами впровадження технологій сталого розвитку щодо казначейського обслуговування клієнтів є: залучення передових інформаційних технологій; використання достовірної інформації; застосування електронного цифрового підпису; сумісність та єдність технічних стандартів; доступність та впорядкованість; конфіденційність та інформаційна безпека; максимальна інтеграція з інформаційними ресурсами органів державної влади; відкритість та прозорість інформації; гарантована схоронність даних.

Кожен рік Міністерство фінансів України (далі - МФУ) затверджує пріоритетні напрями діяльності Державної казначейської служби України. Так, на 2019 р. затверджено такі напрями діяльності: повнофункціональне обслуговування розпорядників (одержувачів) коштів державного бюджету з використанням системи дистанційного обслуговування "Клієнт казначейства Казначейство" (далі - СДО); оптимізація кількості учасників системи електронних платежів Національного банку України (територіальних органів Казначейства) шляхом подальшої централізації інформаційних ресурсів Казначейства; участь у модернізації системи бухгалтерського обліку в державному секторі: консолідація фінансової звітності, складеної згідно 3 національними положеннями (стандартами) бухгалтерського обліку в державному секторі; адаптація облікової системи AC “ $Є$-Казна" та внутрішньої платіжної системи Казначейства до Плану рахунків бухгалтерського обліку в державному секторі; введення в дію програмно-технічного комплексу "Акредитований центр сертифікації ключів “CryptoKDC” шляхом набуття статусу кваліфікованого надавача електронних довірчих послуг; підвищення відкритості та прозорості у діяльності Державної казначейської служби України; участь у запровадженні єдиного рахунку для зарахування митних платежів [2].

Починаючи з 2016 р., органами Казначейства проводиться повномасштабне впровадження СДО клієнтів через програмно-технічний комплекс "Клієнт Казначейства Казначейство” (далі - ПТК “Клієнт Казначейства - Казначейство”), яке надає доступ до ресурсів інформаційного середовища Казначейства в частині формування та передачі до органів Казначейства платіжних документів з використанням електронного цифрового підпису, обміну плановими бюджетними документами (річний розпис призначень державного бюджету, розписи місцевих бюджетів, планові показники, розподіли, кошториси тощо), завантаження інформації щодо бюджетних зобов'язань і бюджетних фінансових зобов'язань, завантаження розподілів відкритих асигнувань і розпоряджень на виділення асигнувань місцевого бюджету, формування та отримання клієнтами Казначей- 
ства електронних виписок по рахунках.

Метою створення СДО розпорядників (одержувачів) бюджетних коштів органами Казначейства $є$ спрощення та оптимізація взаємодії розпорядників (одержувачів) бюджетних коштів 3 органами Казначейства, впровадження електронного формату обслуговування клієнтів 3 використанням надійних засобів електронного цифрового підпису та сучасних інтернет-технологій.

Ключовими моментами, які дають змогу ефективніше здійснювати обслуговування розпорядників (одержувачів) бюджетних коштів всіх рівнів, є: отримання клієнтами можливості в режимі реального часу відстежувати стан рахунків; оптимізація витрат на підтримку процесу обслуговування розпорядників коштів всіх рівнів; досягнення значного економічного ефекту завдяки суттєвій економії часу, зменшення затрат на відрядження, витратні матеріали для друку та транспортування тощо [3].

Переваги для клієнтів у витратах на систему їхнього дистанційного обслуговування через ПТК “Клієнт Казначейства - Казначейство” порівняно 3 іншими on-line системами полягають у безкоштовному: наданні органами Казначейства послуг 3 генерації ключів електронного цифрового підпису; використанні клієнтами системи дистанційного їхнього обслуговування через ПТК “Клієнт Казначейства - Казначейство”; первинному підключенні клієнтів до системи дистанційного обслуговування клієнтів через ПТК “Клієнт Казначейства - Казначейство”; під- тримці клієнтів щодо використання системи дистанційного обслуговування клієнтів через ПТК “Клієнт Казначейства - Казначейство” [4].

15 листопада 2017 р. прийнято розпорядження Кабінету Міністрів України № 816-р, яким рекомендовано визначити пріоритетним казначейське обслуговування через СДО розпорядникам (одержувачам) бюджетних коштів державного та місцевих бюджетів і здійснити організаційно-технічні заходи з підключення до такої системи [5] .

Нині органами Казначейства укладено із клієнтами 32431 договорів на дистанційне розрахункове обслуговування 3 використанням ПТК “Клієнт Казначейства - Казначейство”, у т. ч. 8237 клієнтів фінансуються 3 державного бюджету, 23578 - з місцевого бюджету, 616 - 3 фондів (інших клієнтів або одержувачів бюджетних коштів, відповідно). Здійснено підключення 25 областей, що працюють у системі. При цьому 21268 клієнтів отримують виписки, 16391 - здійснюють платежі [6].

Кількість установ та організацій, включених до Єдиного реєстру розпорядників та одержувачів бюджетних коштів, на сьогодні становить 70632 (2016 р. - 77626); а кількість установ та організацій, підключених до СДО клієнтів через ПТК “Клієнт Казначейства - Казначейство”, становить лише 32730 (2016 р. - 2230) [7]. Кількість установ та організацій, підключених до СДО клієнтів через ПТК “Клієнт Казначейства Казначейство” до загальної кількості установ та організацій, включених до Єдиного реєстру розпорядників та одержувачів бюджетних коштів у 
відсотках становить 46,3 \% (2016 р. 2,9 \%). Тобто, починаючі з 2016 р. майже у 16 разів зросла кількість клієнтів, які виявили бажання працювати в СДО.

Органами Казначейства продовжується роз'яснювальна робота щодо підключення до СДО клієнтів через ПТК “Клієнт Казначейства - Казначейство”. Однак одним з проблемних питань є витрати на придбання захищених носіїв ключової інформації (далі - НКІ) за рахунок коштів клієнтів. Існує певна кількість установ або організацій, які мають статус неприбуткових та отримують кошти як одержувачі бюджетних коштів у результаті перемоги в конкурсах на виконання певних проектів та не завжди мають фінансову спроможність придбати захищені НКІ. Тому необхідно вирішувати питання шляхом можливості застосування альтернативних НКІ, які теж будуть підходити до застосування. Також на практиці виявляється, що при скануванні підтверджуючих документів щодо реєстрації та проведення капітальних видатків спостерігається дуже великий масив інформації, яку необхідно обробити обом сторонам СДО - як Казначейству, так і клієнтам. Також існує проблема відсутності необхідних для роботи з наведеним програмним забезпеченням знань у бухгалтерів в організаціях та установах, що гальмує процес впровадження новітніх технологій. Водночас у даних посадових осіб часто відсутнє навіть бажання використовувати дані програми здебільшого через нестачу часу на навчання.

Одним із напрямів удосконалення автоматизованих процесів фор- мування та виконання бюджетів різних рівнів є електронне звітування 3 використанням інформаційних технологій та електронного цифрового підпису. У рамках реалізації Плану заходів щодо модернізації системи бухгалтерського обліку в державному секторі на 20162018 pp., затвердженого наказом МФУ від 28.11.2016 р. № 1038, Державною казначейською службою України створена та введена в експлуатацію система подання електронної звітності розпорядниками та одержувачами бюджетних коштів і державними цільовими фондами (далі - АC “Є-Звітність”) [8].

AC “Є-Звітність” - це єдиний формат надання електронної звітності клієнтів Казначейства, а також є важливим кроком модернізації системи бухгалтерського обліку в державному секторі. АC "С-Звітність" дає змогу заповнювати в електронному вигляді фінансову звітність, бюджетну звітність, перевірити, підписати електронним цифровим підписом (далі - ЕЦП) кожну форму фінансової звітності та подати до органу Казначейства за місцем обслуговування; головним розпорядникам бюджетних коштів та розпорядникам бюджетних коштів нижчого рівня, до мережі яких включені розпорядники (одержувачі) бюджетних коштів, контролювати стан складання та подання звітності до органу Казначейства підвідомчими установами, дотримання термінів подачі звітності, встановлених органом Казначейства. У разі необхідності своєчасно звертати увагу підвідомчих установ на допущені викривлення (неточності) при заповненні показників у відпо- 
відних формах звітності; здійснювати автоматизовану консолідацію усіх форм фінансової та бюджетної звітності на кожному рівні консолідації; прискорити перевірку органами Казначейства звітності [8].

Станом на 16.01.2019 р. для подання звітності в АС "С-Звітність" розпорядниками (одержувачами) бюджетних коштів створено 46709 електронних кабінетів, а саме: розпорядниками бюджетних коштів державного бюджету - 9998; розпорядниками бюджетних коштів місцевого бюджету - 23529; одержувачами бюджетних коштів - 13182, а також зареєстровано 107358 користувачів, з яких адміністраторів - 733; бухгалтерів - 2050; казначеїв - 3525; керівників - 53592; головних бухгалтерів -47458 [9].

Застосування електронної звітності має низку переваг, а саме: подача звітності за єдиними стандартами; здійснення автоматичного аналізу та перевірки звітності; скорочення часу подання та консолідації звітності; скасування подання звітності на паперових носіях (економія робочого часу та матеріальних витрат); подання звітності через мережу Інтернет; створення електронного архіву звітності.

Висновки i перспективи подальших досліджень. Адаптація та впровадження системи віддаленого доступу клієнтів Казначейства через ПТК "Клієнт казначейства Казначейство" зменшить вплив людського фактору, вірогідність помилок, підвищить безпеку обміну даними, спростить проходження платежів, обслуговування розпорядників (одержувачів) бюджетних коштів усіх рівнів органами Казначейства та підвищить прозорість бюджетного процесу. Запровадження АС " $€$-Звітність" є важливим кроком 3 модернізації системи бухгалтерського обліку в державному секторі, який дасть можливість удосконалити автоматизовані процеси формування та виконання бюджетів різних рівнів, а також досягти якісно нового рівня управління державою, що базується на принципах результативності, ефективності, прозорості, відкритості, доступності, довіри та підзвітності.

3 точки зору архетипного підходу до технологій сталого розвитку в сфері обслуговування клієнтів в органах Казначейства, необхідно зосередити увагу на удосконаленні ПТК “Клієнт Казначейства - Казначейство” та АС "Є-Звітність" з метою спрощення та зменшення навантаження на працівників Казначейства та бухгалтерів, а також розробити більш детальні методичні рекомендації щодо використання програмних продуктів.

\section{СПИСОК ВИКОРИСТАНИХ ДЖЕРЕЛ}

1. Філософія [Електронний ресурс]. Режим доступу: https://studfiles. net/preview/5461486/page:30/

2. Пріоритетні напрями діяльності Державної казначейської служби України на 2019 рік [Електронний ресурс]. - Режим доступу: https://www.treasury.gov.ua/ ua/pro-kaznachejstvo/funkciyi-taprioritetni-zavdannya/prioritetninapryami-roboti/2019

3. Концепція розвитку інформаційних технологій Державної казначейської служби України на 2015-2017 роки : 
лист ДКСУ від 18 лютого 2015 р. № 17-10/202-2929.

4. Переваги для клієнтів у витратах на систему дистанційного обслуговування клієнтів через ПТК "Клієнт Казначейства - Казначейство” порівняно 3 іншими on-line системами [Електронний ресурс]. - Режим доступу: http://www.treasury.gov.ua/ main/uk/publish/article/276806

5. Деякі питання дистанційного обслуговування розпорядників (одержувачів) бюджетних коштів [Електронний ресурс]. Розпорядження Кабінету Міністрів України від 15.11.2017 р. № 816-p. - Режим доступу: https://www.kmu.gov.ua/ua/ npas $/ 250431800$

6. Інформація щодо підключення до системи дистанційного обслуговування клієнтів через ПТК "Клієнт Казначейства - Казначейство” [Електронний ресурс]. - Режим доступу: https://www.treasury. gov.ua/ua/kliyent-kaznachejstvakaznachejstvo/statistika

7. Офіційний сайт Державної казначейської служби України [Електронний ресурс]. - Режим доступу: http://treasury.gov.ua

8. Щодо запровадження АC "С-Звітність”: лист Державної казначейської служби України від 31.01.2018 р. № 14-08/94-1951.

9. Про реалізацію рішення Колегії Державної казначейської служби України від 01.02.2019 р.: наказ Державної казначейської служби України від 14.02.2019 р. № 52.

\section{REFERENCES}

1. Filosofiia [Philosophy]. (n.d.). studfiles.net. Retrieved from https:// studfiles.net/preview/5461486/ [in Ukrainian].

2. Priorytetni napriamy diialnosti Derzhavnoi kaznacheiskoi sluzhby
Ukrainy na 2019 rik, atverdzheni Ministrom finansiv Ukrainy O. Markarovoiu 08.01.2019 [Priority lines of activity of the State Treasury Service of Ukraine for 2019, approved by the Minister of Finance of Ukraine O. Markarova on January 8, 2019]. (2019). www.treasury.gov.ua. Retrieved from https://www.treasury. gov.ua/ua/pro-kaznachejstvo/funkciyi-ta-prioritetni-zavdannya/prioritetni-napryami-roboti/2019 [in Ukrainian].

3. Концепція розвитку інформаційних технологій Державної казначейської служби України на 2015-2017 роки : лист ДКСУ від 18 лютого 2015 р. № 17-10/202-2929.

4. Perevahy dlia kliientiv u vytratakh na systemu dystantsiinoho obsluhovuvannia kliientiv cherez PTK "Kliient Kaznacheistva - Kaznacheistvo" porivniano $\mathrm{z}$ inshymy on-line systemamy [Advantages for customers in the cost of a system of remote customer service through the PTC "Kliient Kaznacheistva - Kaznacheistvo" compared with other on-line systems]. (n.d.). www.treasury.gov.ua. Retrieved from http://www.treasury.gov.ua/ main/uk/publish/article/276806 [in Ukrainian].

5. Rozporiadzhennia Kabinetu Ministriv Ukrainy "Deiaki pytannia dystantsiinoho obsluhovuvannia rozporiadnykiv (oderzhuvachiv) biudzhetnykh koshtiv" : vid 15.11.2017, № 816-r [Order of the Cabinet of Ministers of Ukraine "Some issues of remote servicing of administrators (receivers) of budget funds" from November 15, 2017, № 816-r]. (n.d.). www.kmu. gov.ua. Retrieved from https://www. kmu.gov.ua/ua/npas/250431800 [in Ukrainian].

6. Informatsiia shchodo pidkliuchennia do systemy dystantsiinoho obsluhovuvannia kliientiv cherez PTK "Kliient 
Kaznacheistva - Kaznacheistvo" [Information on connecting to the system of remote customer service through the PTK "Kliient Kaznacheistva Kaznacheistvo"]. (2018). www.treasury.gov.ua. Retrieved from https:// www.treasury.gov.ua/ua/kliyent-kaznachejstva-kaznachejstvo/statistika [in Ukrainian].

7. Ofitsiinyi sait Derzhavnoi kaznacheiskoi sluzhby Ukrainy [Official site of the State Treasury Service of Ukraine]. treasury.gov.ua. Retrieved from http:// treasury.gov.ua [in Ukrainian].

8. Shchodo zaprovadzhennia AS "Ye-Zvitnist" lyst Derzhavnoi kaznacheiskoi sluzhby Ukrainy vid
31.01.2018, № 14-08/94-1951 [Regarding the introduction of the E-Reporting System, a letter from the State Treasury Service of Ukraine dated 31.01.2018, № 14-08/94-1951]. (2018). www.visnuk.com.ua. Retrieved from http://www.visnuk.com. ua/uk/document/100007172-schodo-zaprovadzhennya-as-ye-zvitnistlist-derzhkaznacheystva-ukrayinivid-31-01-2018-no-14-08-94-1951 [in Ukrainian].

9. Про реалізацію рішення Колегії Державної казначейської служби України від 01.02.2019 р.: наказ Державної казначейської служби України від 14.02.2019 р. № 52. 